\title{
NAUJAGIMIO NUŽUDYMO TEISINIAI IR MEDICININIAI ASPEKTAI
}

\author{
Rita Aliukonienè $\dot{1}^{1}$ Alvydas Navickas ${ }^{2}$, Aurèja Bareikytè ${ }^{2}$ \\ ${ }^{1}$ Vilniaus universiteto Teisès fakultetas, ${ }^{2}$ Vilniaus universiteto Medicinos fakultetas
}

Raktažodžiai: nusikalstama veika, ribotas pakaltinamumas, naujagimio nužudymas, neonaticidas, gimdymo nulemta būsena, psichikos sutrikimas.

\section{Santrauka}

Tarptautinè bendruomene iš visų prigimtinių žmogaus teisių prioritetu laiko žmogaus teisę i gyvybę. Dèl šios priežasties daugumos valstybiu baudžiamuosiuose ịstatymuose numatyti atskiri skyriai, skirti nusikaltimams žmogaus gyvybei reglamentuoti. Taigi ir Lietuvos Respublikos baudžiamasis kodeksas (toliau tekste - BK), ìsigaliojęs nuo 2003 m. gegužès $1 \mathrm{~d}$., saugo ir gina kiekvieno žmogaus teisę ị gyvybę kaip visų kitų teisių pagrindą, nes jei nèra gyvybès, beprasmès tampa ir visos kitos žmogaus teisès [1]. Naujajame Lietuvos baudžiamajame įstatyme įtvirtinta plati vertybiu ir prioritetų sistema, todèl suprantama, kad kai kurių BK normų taikymas teismų praktikoje kelia probleminių klausimų, reikalaujančių gilesnès analizès. Vienas iš tokių probleminių klausimų - naujagimio nužudymo (BK 131 str.), padaryto ribotai pakaltinamos motinos, teisingas atribojimas nuo savo kūdikio nužudymo (BK 129 str. 2 d. 3 p.), kurị padaro psichikos sutrikimų neturinti ir pakaltinama motina.

Medicininès, teisinès literatūros studijos bei baudžiamujjų bylų medžiagos ir jose esančios teismo psichiatrinès - psichologinès ekspertizès leido padaryti išvadą, kad vienas iš pagrindinių kriterijų, suteikiančių teisę patraukti kaltininką baudžiamojon atsakomybẻn už privilegijuotą nužudymą (BK 131 str.), yra nustatymas, kad savo naujagimio nužudymą veikè motinos nulemta gimdymo būsena.

\section{Ivadas}

Atsižvelgiant ị tai, kad nusikalstamos veikos yra klasifikuojamos pagal pavojingumo laipsni, baudžiamajame îstatyme įtvirtintos nužudymų sudètys klasifikuojamos į: 1) pagrindinę sudètį, numatytą BK 129 str. 1 d., kai nèra požymių, didinančių ar mažinančių nužudymo pavojin- gumą; 2) kvalifikuotą sudètí, numatytą BK 129 str. 2 d., esant aplinkybėms, didinančioms nužudymo pavojingumą; 3) privilegijuotą sudèti, numatytą BK 130 str. ar 131 str., esant nužudymo pavojingumą mažinančioms aplinkybėms. Siekiant pateikti privilegijuoto nužudymo sampratą, būtina remtis ne tik bendraisiais nužudymo požymiais, t. y. tyčiniu kito žmogaus gyvybės atemimu, veikos pavojingumu ir neteisètumu, bet ir specialiaisiais požymiais - tam tikra kaltininko būsena, kuri daro įtaką ji padaryti nusikalstamą veiką, nes tokioje būsenoje nesantis asmuo taip nesielgtų, t. y. nepadarytų nusikaltimo. Tokia specifinè nusikalstamą veiką padariusio asmens būklè (naujagimio nužudymo atveju - gimdymo nulemta būsena) ir yra tam tikras požymis, dèl kurio asmuo netraukiamas baudžiamojon atsakomybẻn už paprastą ar kvalifikuotą nužudymą, kadangi ịstatymų leidejjas tokioje būklejje esančio asmens veiką laiko privilegijuotu nusikaltimu ir suteikia tam tikrą „lengvatą“" sankcijoje numatytos bausmès atžvilgiu. Baudžiamosios teisès doktrinoje privilegijuotas nužudymas dažniausiai apibrěžiamas kaip tyčinis kito žmogaus gyvybès atemimas, kurio padarymui ịtakos turi kaltininko emocinė būklè. Be to, būtina pabrèžti, kad baudžiamosios teisès teorijoje žmogaus gyvybès pradžia yra pripažįstama gimdymo pradžia, todèl prasidejjus fiziologiniam gimdymui, naujagimis jau laikomas žmogumi, nors dar ir nèra visiškai išęjęs iš motinos įsčių [2].

Naujagimio nužudymo, kaip ir visų nusikalstamų veikų, už kurias baudžiamasis ịstatymas numato atsakomybę, būtinasis sudèties požymis yra šio nusikaltimo subjektas, nes nusikalstama veika negalima be ją padariusio asmens [3]. Galima teigti, kad būtent naujagimio nužudymo subjektas ir jo ypatumai suteikia galimybę atriboti ši nusikaltimą nuo kitų nužudymų. Naujagimio nužudymo subjektas yra specialusis, t. y. motina, kurią traukiant baudžiamojon atsakomybèn, būtina nustatyti ir bendruosius nusikalstamos veikos subjekto požymius, t. y. motinos amžiu bei pakaltinamumą. Pagal BK 13 str. 1 ir 2 d., atsakomybè už naujagimio nužudymą iškyla tik motinai, kuri nusikalstamos veikos padarymo metu yra sulaukusi 16 metų. Atsižvelgiant $\mathfrak{i}$ tai, kad naujagimi gali pagimdyti ir jaunesnio 
amžiaus motinos, tiek Lietuvos, tiek užsienio šalių baudžiamosios teisès teorijoje keliama diskusija dèl motinos, nesulaukusios 16 metų ir nužudžiusios savo naujagimį, jai buvus gimdymo nulemtoje būsenoje, veikos kvalifikavimo. Pažymètina, kad Lietuvoje už naujagimio nužudymą motinai baudžiamoji atsakomybè pagal BK 131 str. nekyla, jeigu ji nèra sulaukusi 16 metų amžiaus.

Dar vienas bendrasis nusikalstamos veikos subjekto požymis - pakaltinamumas, kuris yra teisinè sąvoka, apibūdinanti nusikalstamos veikos subjekto psichinę būseną, t. y. gebejjimą nusikalstamos veikos darymo metu suprasti savo veiksmų esmę ir juos valdyti. Tačiau pabrèžtina, kad motina traukiama baudžiamojon atsakomybèn tik tada, kai ji nužudo savo naujagimi paveikta gimdymo nulemtos psichinès būsenos, kuri dèl savo esmès vertinama ribotu pakaltinamumu. Tai reiškia, kad ribotai pakaltinamas asmuo suvokia daromos nusikalstamos veikos faktines aplinkybes bei socialinę reikšmę, ir nors toks suvokimas yra siauresnis nei kitų pakaltinamų žmonių, tačiau toks asmuo turi atsakyti už padarytą nusikaltimą [13]. Baudžiamosios teisès teorijoje ribotas pakaltinamumas apibréžiamas kaip tokia žmogaus būsena, kuri nusikalstamos veikos darymo metu neleido jam visapusiškai suprasti savo veiksmų pobūdžio ar juos valdyti dẻl psichikos sutrikimų, kurie nebuvo pakankamu pagrindu pripažinti jị nepakaltinamą. Kita vertus, toks riboto pakaltinamumo apibrèžimas nèra visiškai aiškus, nes jau pačios sąvokos ,psichikos sutrikimas“ vartojimas baudžiamojo įstatymo apibréžime (BK 18 str. 1 d.) sukelia tam tikrą painiavą, kadangi tokio sutrikimo kategorija apima ne tik psichikos defektus, bet ir reaktyvias būsenas, kai žmogaus psichika dèl tam tikrų veiksnių sutrinka tik trumpam laikotarpiui (pvz., pogimdyminè depresija). Nepaisant to, palaikytina pozicija, kad toks laikinas gebejjimo visiškai kontroliuoti ir valdyti savo veiksmus sumažejjimas plačiaja prasme priskirtinas prie psichikos sutrikimų, pripažistant, kad asmuo, padaręs nusikalstamą veiką tokioje psichikos būsenoje, yra ribotai pakaltinamas [11].

Darbo tikslas - išanalizuoti naujagimio nužudymo medicininius bei juridinius kriterijus ir apibūdinti gimdymo nulemtos būsenos sampratą, atsižvelgiant ị aktualias baudžiamosios teisès, psichiatrijos mokslų koncepcijas bei teismų praktiką.

\section{Darbo objektas ir metodai}

Šiame darbe tiriama gimdymo nulemta būsena kaip vienas iš pagrindinių kriterijų, leidžiančių atriboti privilegijuotą nusikalstamą veiką - naujagimio nužudymą nuo kvalifikuoto nužudymo. Tyrimas atliktas remiantis baudžiamųjų bylų ir Valstybinès teismo psichiatrijos tarnybos atliktų ekspertizių medžiagos analize bei Lietuvos ir užsienio vals- tybiu moksline literatūra. Tyrimo metu naudoti lingvistinis, gramatinis, sisteminis, lyginamasis, aprašomosios statistikos ir loginès analizès metodai. Naudojant lingvistinį ir gramatinį metodą, darbe atskleidžiamos vartojamų sąvokų reikšmès. Loginiu, lyginamuoju ir sisteminiu pažinimo metodais įvertintos teisès, medicinos, psichiatrijos, psichologijos mokslininkų nuomonès tiriamos temos aspektais.

\section{Tyrimo rezultatai ir jų aptarimas}

Nagrinėjant naujagimio nužudymo sudètí, būtina atkreipti dėmesí, kad BK gimdymo nulemtos būsenos neapibrèžia, todèl jos sampratą galima pateikti remiantis medicinos, psichologijos mokslais ir baudžiamosios teisès doktrina. Visiškai sutiktina su nuomone, kad jokia situacija pati savaime negali būti vertinama kaip neigiamai veikianti žmogaus psichiką, todèl atsakyti, ar galèjo gimdymas nulemti patologinę motinos būseną, galima tik po išsamaus situacijos ir asmenybès sąveikos įvertinimo [14].

Tarp medicinos, psichologijos, teisès mokslininkų yra nevienareikšmiškos nuomonès dèl gimdymo nulemtos būsenos, nes vieni šiai būsenai priskiria nėštumą, gimdymą ir pogimdymini laikotarpi, prasidedanti po gimdymo, kiti - tik pastaraji laikotarpi, treti teigia, jog gimdymo būsena tęsiasi iki tol, kol trunka klinikinè gimdos evoliucija ir pan. $[7,8]$. Mūsų nuomone, ypatingą motinos psichologinę būseną gali lemti ne vien tik gimdymo procesas, kadangi tokia būsena gali pradèti formuotis nuo nèštumo pradžios arba jo metu. Neabejotina, kad néštumo metu gali susiformuoti tam tikros aplinkybès ar veiksniai, galintys vèliau turèti ittakos gimdymo nulemtai būsenai atsirasti. Kai kurie mokslininkai tokius veiksnius laiko ikigimdymine depresija, teigdami, jog nemaža dalis pogimdyminių nuotaikos sutrikimu gali prasidèti jau nèštumo eigoje, todèl ikigimdymine depresija dar labiau padidina pogimdyminès depresijos išsivystymo riziką [16]. Tokia pozicija, kad moters patologinę būseną gali nulemti ne tik gimdymo metu, bet ir nėštumo metu atsiradę veiksniai, atsispindi ir teismų praktikoje. Pvz., Ukmergès rajono apylinkès teismas baudžiamojoje byloje pripažino R. B. kalta dèl savo naujagimio nužudymo gimdymo nulemtoje būsenoje pagal BK 131 str., remdamasis ekspertizès aktu, kuriame nurodoma, kad dar ilgainiui iki gimdymo dèl objektyvių (nepageidaujamas, nesantuokinis néštumas, neturi galimybès pasidaryti abortą, sunki materialinè šeimos padètis, būtinybė aprūpinti vaikus) bei subjektyvių (tiriamosios asmenybès bruožai - pasyvumas, neryžtingumas, uždarumas, introversinis išgyvenimų tipas, menki gebejimai konstruktyviai veikti frustruojančiose situacijose ir kt.; jos emociniai išgyvenimai - gèda ir baimé, kad aplinkiniai sužinos apie něštumą; pasimetimas ir sutrikimas, nerandant problemos sprendimo 
būdų) priežasčių tiriamoji R. B. galejjo apsispręsti neauginti būsimo naujagimio, nes tai patvirtina něščiosios elgesys, t. y. atkaklus nèštumo slèpimas [23].

Atkreiptinas dėmesys, kad tarp teisininkų egzistuoja ir kardinaliai priešingų nuomonių, teigiant, jog traukiant motiną baudžiamojon atsakomybèn už naujagimio nužudymą dèl gimdymo nulemtos būsenos, pakanka nustatyti, kad naujagimio nužudymas buvo padarytas dèl stipraus pergyvenimo, sukelto gimdymo proceso ir jo eigos, o jokios kitos pergyvenimo priežastys, tokios kaip vaiko neigalumas ar kitokia gimdyvès sunki asmeninè padètis, nèra svarbios ir reikšmingos [15]. Tačiau mes palaikome tuos autorius, kurie su minèta pozicija nesutinka, teigdami, kad yra daug veiksnių, veikiančių moters psichologinę būseną tiek nèštumo, tiek gimdymo, tiek ir pogimdyminiu laikotarpiu, kurie gali nulemti motinos būseną [4]. Dažniausiai mokslinèje literatūroje: dèl moters patiriamų pogimdyminių emocinių pokyčių, sveikatos problemų, gimdymo nulemta būsena klasifikuojama ị tris pagrindines grupes [5]:

1. Pogimdyminis liūdesys - tai emocinès būklès patologija, kai pasireiškia ne visi depresijai būdingi požymiai, o tik jų dalis. Pogimdyminis liūdesys labiausiai paplitęs iš sutrikimų ir nustatomas apie $50-80 \%$ pagimdžiusių moterų. Emocinio nestabilumo požymiai paprastai atsiranda antrą ir trečią dieną po gimdymo, o labiausiai išryškèja 5-7 dieną, kai moteriai pasireiškia kintanti nuotaika (tai didelis džiaugsmas, tai verksmingumas, nerimas, miego sutrikimai, apetito sumažèjimas, liūdesys, dirglumas, apatija ir pan.

2. Pogimdyminè depresija - tai sutrikimas, kuris prasideda po gimdymo, dažniausiai ne vèliau kaip ketvirtą savaitę, bet kai kuriais atvejais ir vèliau, netgi pirmaisiais metais po gimdymo. Tokia depresija atsiranda dèl moters organizmo psichologinio ir biologinio pažeidžiamumo, susijusio su gimdymu ir šiam sutrikimui būdingi dèmesio sutelkimo pokyčiai, savęs nuvertinimas, kaltès jausmas, kad nèra gera motina, pesimistinès nuotaikos, miego sutrikimai, apetito stoka ir pan. Pavojingiausiai depresija pasireiškia mintimis apie savižudybę ar savo naujagimio nužudymą. Apie $85 \%$ motinų po gimdymo jaučia depresiją, galinčią sukelti neapykantą ir pyktị naujagimiui, o kartu ir grèsmę jo gyvybei, taip pat savižudiškus moters veiksmus [6].

3. Pogimdyminė psichozė - sunkus gimdyvès nuotaikos sutrikimas, kuris dažniausiai prasideda pirmomis dienomis po gimdymo, formuojantis būklei, panašiai ị hipomaniją. Pagrindiniai pogimdyminès psichozès simptomai yra moters susijaudinimas, forsuota kalba, haliucinacijos, kliedesiai, nemiga, noras nužudyti savo naujagimi ir taip apsaugoti jị nuo kančių ateityje [12].

$2014 \mathrm{~m}$. Lietuvoje buvo atliktas tyrimas, analizuojantis neonaticidą (naujagimio nužudymas per 24 val.) padariusių motinų psichinę būklę ir ją lydinčius veiksnius. Šio tyrimo metu nustatyta, kad $56 \%$ tiriamųų turejo tokius psichikos sutrikimus kaip depresija, dirglumas, išsekimas ir apatija. Iš 62 tiriamųjų, nužudžiusių savo naujagimius, $61 \%$ buvo nustatyta tam tikras psichikos sutrikimas, o $18 \%$ tiriamųjų buvo pripažintos nepakaltinamomis [9]. Kaip jau buvo minèta, BK konkrečiai neapibrèžia pogimdyminès būklès ir ją ịvardija „gimdymo nulemta būsena“. Atsižvelgiant ị tai, kad tokios būklès visi galimi pasireiškimo būdai yra alternatyvūs, manytina, kad nusikalstamos veikos kvalifikavimui jie reikšmès neturi.

Svarbu paminèti, kad Lietuvos teismai savo sprendimuose, remdamiesi ekspertų išvadomis, ne tik ịvardija konkrečią kaltininkès būseną, pvz., ,priklausomo tipo asmenybès sutrikimas“, „situacinè depresinè reakcija“, „adaptacijos sutrikimo lygis“, tačiau nurodo ir konkrečius tiek objektyviai, tiek subjektyviai kaltininkę ir jos būseną apibūdinančius požymius, pavyzdžiui, Ukmergès rajono apylinkès teismo baudžiamosios bylos nuosprendyje rašoma, kad kaltinamosios R. B. elgesyje vyrauja specifinio asmenybès sutrikimo simptomatika, kurią patvirtina psichologinio asmenybės tyrimo duomenys: pasyvumas, neryžtingumas, uždarumas, introversinis išgyvenimų tipas, nepasitikejjimas savimi, diskomforto, bejëgiškumo ir baimès jausmas, kad nesugebès pasirūpinti savimi, polinkis užimti pasyvaus laukimo poziciją, pati neieško racionalių situacijų sprendimo būdų. Šioje byloje esančiose teismo psichiatrinès psichologinès ekspertizès medžiagoje nurodoma, kad tiriamosios elgesiui gimdymo metu ir tuoj po jo (buvo pasyvi stebetoja, visiškai nesirūpino savo naujagimiu ir kt.) galèjo tureti ịtakos ir pats gimdymo procesas, (t. y. ypatinga psichofiziologinè būsena, lydima intensyvių skausmų), o laikotarpiu po gimdymo - fizinis ir psichinis išsekimas, apatijos aplinkai jausmas, todèl buvo padaryta išvada, kad kaltinamoji turi priklausomumo tipo sutrikimą, situacinę depresinę reakciją [23].

Kita vertus, kai kuriuose teismo nuosprendžiuose pasigendama išsamių argumentų ir motyvacijos. Pvz., nors kaltinamoji V. P. buvo pripažinta kalta už savo naujagimio nužudymą pagal BK 131 str., tačiau nuosprendyje nebuvo išanalizuoti veiksniai, kurie galèjo sukelti kaltininkei psichikos sutrikimą, t. y. gimdymo nulemtą būseną [20]. Pažymètina, kad teismų praktikos analizè leidžia teigti, jog visapusiškas ir nuodugnus kaltininkès būsenos tyrimas turi būti atliekamas visose baudžiamosiose bylose dèl naujagimio nužudymo, nes išsamiai neištyrus motinos būsenos, ji gali būti nepagrįstai nuteista ne už privilegijuotą nusikaltimą naujagimio nužudymą, o pagal BK 129 str. 2 d. 1, 2, 3 punktus, t. y. už žymiai sunkesnị kvalifikuotą nužudymą [21]. Atkreiptinas dėmesys, kad tais atvejais, kai motina nužudo 
savo naujagimį bendrininkaudama su kitais asmenimis, pastarujų veika pagal BK 131 str. nekvalifikuojama, nes ji neatitinka šios nusikalstamos veikos sudèties subjekto požymių. Tokiems bendrininkams inkriminuojami BK 129 str. 2 d. atitinkami punktai ir BK bendros dalies normos, reglamentuojančios bendrininkų baudžiamają atsakomybę [18].

Taigi neabejotina, kad naujagimių nužudymų tyrimo atvejais, motinos gimdymo nulemtai būsenai nustatyti ypatingą reikšmę turi psichologinès, psichiatrinès ekspertizès išvados. Antai Panevėžio apygardos teisme buvo paneigta kaltinamosios versija, kad ji gimdymo metu buvo nualpusi ir netekusi sąmonès, todèl neprisimena kaip suvyniojusi naujagimi ị rankšluostị ir ịdejjusi ji ị polietileninị maišelị, pakišo ji po vonia, nuo ko jis dèl uždusimo mirè. Byloje buvo duota teismo psichologinès-psichiatrinès ekspertizès išvada, kad kaltinamoji taip elgèsi sąmoningai, nes veikos padarymo metu galejjo suprasti savo veiksmų pavojingumą ir juos valdyti [19].

Pažymėtina, kad pasitaiko atvejų, kai atliekamos kelios ekspertizès, pvz., kasaciniame skunde nuteistoji rašé, kad jos psichine būklè nebuvo tirta išsamiai, o tik formaliai stebèta. Tačiau bylos medžiaga rodo, kad kaltininkei L. V. buvo atlikta ne tik ambulatorine, bet ir stacionarinè psichologinè, psichiatrinè ekspertizè. Ambulatorinès ekspertizès akte nurodyta, kad baudžiamosios bylos medžiagoje ir medicininiuose dokumentuose nèra duomenų, leidžiančių padaryti išvadą, jog L. V. nusikalstamos veikos padarymo metu būtų buvusi laikinoje psichinès veiklos sutrikimo, t. y. gimdymo nulemtoje būsenoje. Ekspertų komisija, stacionariai stebèjusi L. V. ir išanalizavusi bylos medžiagą, padarè kategorišką išvadą, kad kaltinamoji veikos padarymo metu nebuvo laikinoje psichikos veiklos sutrikimo - gimdymo nulemtoje būsenoje ir galèjo suprasti savo pavojingų veiksmų esmę ir juos valdyti [17].

Baigiant šị tyrimą, paminètina dar viena baudžiamoji byla, kurioje buvo nustatyta, kad kaltinamoji viena gimdydama moteriškos lyties kūdikị, neatsargiai suspaudè naujagimès kaklą bei smakrą ir dèl patirtų sužalojimų naujagimè mirè. Teismas konstatavo, kad kaltinamoji atėmè savo naujagimès gyvybę neatsargiai ir nuteisé ją pagal BK 132 str. [22]. Manytina, kad toks teismo sprendimas yra teisètas ir pagrịstas, nes neatsargiai (nusikalstamu pasitikejjimu arba nusikalstamu nerūpestingumu) atėmus naujagimio gyvybę, motinai naujagimio nužudymas (BK 131 str.) neinkriminuojamas, nes ji atsako pagal BK 132 str., t. y. už neatsargu gyvybès atèmimą.

\section{Išvados}

1. Privilegijuotas nužudymas - tai tyčinis kito žmogaus gyvybès atemimas, kuriam padaryti įtakos turi kaltininko emocinè būklè.

2. Naujagimio nužudymo subjektas yra specialusis, t. y. motina, kurią traukiant baudžiamojon atsakomybèn, būtina nustatyti ir bendruosius nusikalstamos veikos subjekto požymius, t. y. motinos amžių bei pakaltinamumą.

3. Motina traukiama baudžiamojon atsakomybèn pagal BK 131 str. tik tada, kai ji nužudo savo naujagimi paveikta gimdymo nulemtos psichinès būsenos, kuri dèl savo esmès vertinama ribotu pakaltinamumu.

4. Ypatingą motinos psichinę būseną gali lemti ne vien tik gimdymo procesas, nes tokia būsena gali pradèti formuotis nuo nèštumo pradžios arba jo metu, t. y. atsirasti tam tikros aplinkybès ar veiksniai, galintys vèliau turèti ịtakos gimdymo nulemtai būsenai atsirasti.

5. Baudžiamasis kodeksas konkrečiai neapibrěžia pogimdyminès būklès ir ją ịvardija ,gimdymo nulemta būsena“. Atsižvelgiant i tai, kad tokios psichinès būsenos visi galimi pasireiškimo būdai yra alternatyvūs, manytina, kad nusikalstamos veikos kvalifikavimui jie reikšmès neturi.

6. Naujagimių nužudymų tyrimo atvejais motinos gimdymo nulemtai būsenai nustatyti ypatingą reikšmę turi psichologinès, psichiatrinès ekspertizès išvados.

\section{Literatūra}

1. Lietuvos Respublikos baudžiamasis kodeksas (su pakeitimais ir papildymais). Valstybès žinios, 2000; (26-1968).

2. Abramavičius A., Baranskaitė A., Milinis A. Probleminiai žmogaus gyvybės pradžios ir pabaigos klausimo aspektai nužudymo kontekste. Jurisprudencija, 2011; 18 (3): 1126.

3. Aliukonienė R. Sunkaus sveikatos sutrikdymo sudèties, numatytos Lietuvos Respublikos baudžiamojo kodekso 135 straipsnyje, subjekto samprata. Globalizacijos iššūkiai baudžiamajai justicijai. Vilnius, 2014; 156.

4. Arenson J., Drake P. Maternal and Newborn Health. Psychological Adaptation to pastpartum. London, 2007; 154-157.

5. Burns D. Aspects of Postpartum Depression. London, 2003; 78.

6. Danilevičiūtė V. Psichikos sutrikimai nėštumo ir pogimdyminiu laikotarpiais. Kaunas, 2006; 14-18.

7. Daubaras G. Somatinių ligonių psichikos sutrikimai. Vilnius, 2001; 108-109.

8. Drasutienè G., Venckauskas A. Akušerijos ir ginekologijos praktikos vadovas. Vilnius, 2003; 200.

9. Jasulaitis A., Stasiūnienė J., Chmieliauskas S., Andruškevičiūtė G. Motinų agresijos, nukreiptos ị savo kūdikius, priežastys ir jas lemiantys veiksniai. Medicinos teorija ir praktika, 2014; 20(1):29.

10. Lapkauskienè N. Psichikos sveikatos sutrikimai ir slaugos pagrindai. Mokomoji knyga. Vilnius, 2004; 82.

11. Meška A. Riboto pakaltinamumo sąvoka. Lietuvos Respublikos baudžiamajam kodeksui - 10 metų. Vilnius, 2011; 241.

12. Nonacs R, Cohen LS. Postpartum mood disorders: Diagnosis 
and treatment, Guidelines. 1998; ( 59): 37.

13. Piesliakas V. Lietuvos baudžiamoji teisè. Pirmoji knyga. Vilnius, 2006; 331.

14. Safuanov F. Ekspertiza sostojanija materi obviniajamoi v ubijstve novoroždionogo rebionka. Rosijskaja justicija, 1998; (3): 29-31.

15. Tyszkiewicz L. et al. Kodeks karny. Komentarz. Warszawa, 2010; 114-115.

16. Zinga D, Phillips SD, BL. Postpartum depression: we know the risks, can it be prevented? Psiquiatr 2005; 27 (2):54-65.

\section{Teismų praktika:}

17. Lietuvos Aukščiausiojo Teismo nutartis baudžiamojoje byloje Nr. 2K-283/2006.

18. Lietuvos apeliacinio teismo nuosprendis baudžiamojoje byloje Nr. 1A-106/2014.

19. Panevėžio apygardos teismo nuosprendis baudžiamojoje byloje Nr. 1-44-350/2014.

20. Prienų rajono apylinkès teismo nuosprendis baudžiamojoje byloje Nr. 1-72-214/2005.

21. Šiaulių apygardos teismo nuosprendis baudžiamojoje byloje Nr. 1-6-300/2013.

22. Šiaulių apygardos teismo nuosprendis baudžiamojoje byloje Nr. 1-19-332/2011.

23. Ukmergès rajono apylinkès teismo nuosprendis baudžiamojoje byloje Nr. 1-26-161/2010.

\section{MURDER OF NEWBORN: LEGAL AND MEDICAL ASPECTS}

\section{R. Aliukonienė, A. Navickas, A. Bareikytė}

Key words: criminal act, limited responsibility, homicide of a newborn, neonaticide, childbirth determined by condition, mental disorder.
Summary

The international community claims that the right to life is a priority, compared to all other inherent human rights. Due to this reason, the majority of criminal laws in different countries provide individual chapters on the regulation of crimes against human life. Therefore, the Criminal Code of the Republic of Lithuania (hereinafter - the Criminal Code), which has entered into force on May $1^{\text {st }}$ of 2003, protect and defend the right to life, as the basis for other rights, because all other human rights are meaningless, unless there is life [1]. The new criminal law of Lithuania embeds a broad system of values and priorities; therefore, it is understandable that the application of some $\mathrm{CC}$ norms raises some issues in the judicial practice and requires further analysis. One of such issues - a just separation between the homicide of a newborn (CC art. 131) committed by a mother with limited responsibility and the homicide of a newborn (CC art. 129 c. 2 p. 3) committed by a responsible mother without mental disorders.

The analysis of medical, legal literary research, criminal cases and their judicial psychiatric-psychological examinations allows concluding that one of the main criteria, granting the right to punish the perpetrator for the privileged homicide (CC art. 131), is to determine whether the homicide of a newborn was influenced by mother's childbirth condition.

Correspondence to: rita.aliukoniene@prokuraturos.1t

Gauta 2015-11-19 